\title{
eSport: Towards a Hermeneutic of Virtual Sport
}

\author{
eSport: hacia una hermenéutica del deporte virtual
}

\author{
Antonio Sánchez Pato ${ }^{1}$, Joshua Davis Remilllard ${ }^{2}$ \\ 1 Universidad Católica de Murcia \\ 2 Penn State University
}

CORRESPONDENCIA:

Antonio Sánchez Pato

apato@ucam.edu

\begin{abstract}
Our goal in this paper is to provide a hermeneutical reflection on the possibility of regarding active video games as actual sports (eSports). We will start our analysis with an epistemological analysis on virtual reality. To do so, we will draw the boundaries between virtual and real, providing a concept, or operational definition, of virtual reality. Then, we will build upon this definition to understand what is real within the virtual, as well as the semantic field that virtual reality, using Heideggerian terms, "discloses." This disclosure will be understood as the culmination of philosophy in Western history, where the current dominance of art and the consummation of metaphysics overlap, resulting in what Heidegger calls "the oblivion of Being." To analyze it, we will draw on Aristotle's pair of concepts "dýnamis" and "enérgeia." The latter refers to "being" or "presence," and the former to "essence." In line with this, we will draw on Pierre Lévy's conceptualization of the virtual to describe the process that has led humans to transform their naturally inherited playful instinct into play, and play into sport. To conclude, we will argue that esports are the ultimate goal of a utopian humanization process developed through play.
\end{abstract}

Key words: eSports, virtual, real, hermeneutics.

\section{Resumen}

Nuestro objetivo en este artículo es ofrecer una reflexión hermenéutica sobre la posibilidad de considerar a los videojuegos (eSports) como deportes auténticos. Comenzaremos nuestro análisis con un análisis epistemológico de la realidad virtual. Para ello, trazaremos los límites entre lo virtual y lo real, proporcionando un concepto, o definición operativa, de la realidad virtual. Seguidamente, avanzaremos sobre esta definición para comprender qué es real dentro de lo virtual, así como el campo semántico que la realidad virtual -usando términos hedeggerianos-, "revela". Esta revelación será entendida como la culminación de la filosofía en la Historia Occidental, donde el actual dominio del arte y la consumación de la metafísica se superponen, dando como resultado lo que Heidegger Ilamó "el olvido del Ser". Para este análisis, recurrimeros al binomio de conceptos artistotélicos de "dynamis" y "enérgia". Éste último se refiere al "ser" o "presencia", y el primero a la "esencia". En relación a esto, recurriremos a la conceptualización de Pierre Levy acerca de lo virtual para describir el proceso que ha guiado a los humanos a transformar su instinto lúdico en juego, y el juego en deporte. Para concluir, argumentaremos que los eSports son el objetivo final del proceso de humanización utópico desarrollado a través del juego.

Palabras clave: eSports, virtual, real, hermeneútica. 


\section{Introduction and objectives}

Sports are the result of the culture and values of the time in which they emerge: "[Sport] is a temporary and topographical phenomenon, that is to say, it is an activity which is rooted in a certain time and place" (Garcia, 2005, p. 94). However, sports also arise by abstracting (simplification) from their context. For example, the sport of hunting emerges because of abstraction from the survival aspects of hunting as a nourishing activity. If we further extend this idea, we can see that virtual sports arise from the elimination of physical reality. Despite the separation of virtual sport from physical reality, in this paper we will argue that virtual sports should still be regarded as sports as long as they retain their recreational and competitive elements. Our goal in this article is to make an argument for the consideration of video games as sports (albeit electronic sports, or eSports). To do so, first, we will draw on Heidegger's analyses on the nature of technology to delineate the limits between the virtual and the real (Heidegger 1977, 3-36). In doing this, we locate the analysis of sport ${ }^{1}$ within that of the analysis of modern technology. Second, our hermeneutic approach to sport will explore the changes in meaning that occur when we are involved in practicing sport, whether in physical space or a virtual environment. This issue will be addressed by relying on Pierre Lévy's conception of the virtual as a powerful way of Being that emphasizes the processes of creation. Third, we will describe the process that has led men from work to play, from play to games, and from games to sport through the repeated application of virtualization. We will regard this process as a milestone in the utopian self-realization of humanity through play (Sánchez, 2012; Sánchez and Martinez, 2014).

\section{Virtual(ity), Real(ity), and Present(ly)}

Sport often operates in a real and present environment, however it can also operate in a virtual environment (through the process of virtualization), maintaining its playful elements while dissipating its elements rooted in reality, because "there is virtuality in the real and reality in the virtual" (Echeverría, 2000 , p. 43). It is in the hyperspace of virtual reality that we set our sport-themed virtual games. This process operates both ways, in the conversion of sport

1 Our definition of sport was explained in depth in Sánchez, A. y Mosquera, M.Ja. (2011). Treaty on Violence and Sport, Sevilla: Wanceulen, in its chap. 4 (Defining Sport), pp. 95-105. to (virtual) game, and the conversion of (virtual) game to sport (real and present, although virtual). The creation of new virtualizations is commonplace in the evolution of human culture: "The invention of new technologies opens up radically new possibilities in which developments create their own autonomous world, an arborescent creation in which no static utility criterion can be found" (Lévy, 1999, p. 78). To illustrate this point, we can understand that while airplanes allow us to actually fly, human beings have always "flown" with their imagination, for instance, simulating flight with cardboard wings. Technology is crucial to this flight of human imagination, because the advances in technology enable humans to reinvent their tools, capabilities, and possibilities.

New generations take for granted that which was unthinkable for previous generations. For digital natives (Prensky, 2001), video game consoles are playful operators. Similarly, cars are transportation operators in contemporary society (Lévy, 1999). Both video games and cars may seem strange or ridiculous to generations which have lived without that technology. In this sense, sports played in a virtual reality (VR) might also seem strange to those unaccustomed to them. These do not replace sports or the activities that inspire them, nor are they substitutes; they are new sports, a virtualization, as the motorcycle is to the bicycle, operating in another area of virtualization. Moreover, some argue that, "virtuality is more real than reality” (Quéau, 1995, p. 74), since virtuality is able "to replace deficits in our traditional reality" (Echeverría, 2000, p. 138).

One's avatar moves in a cyberspace, or a virtual threedimensional world (Echeverría, 2000, p. 94), where there are more possibilities than in modern sport ${ }^{2}$ (Mandell, 1986). This allows to expand upon: a) play spaces (virtual space) to almost abstract limits; b) time (overcoming the barriers of day or night) beyond our traditional chronology; c) the players' mentality (capable of unthinkable, even oneiric dream actions), who become transgressors; $d$ ) the game itself (where the avatar who represents me in the screen is an extension of oneself, adopting different simultaneous roles); and e) the materials (totally multifunctional and versatile) which become self-implanted implements. In virtual sports, playgrounds are projected into our living rooms through a screen that takes us to a

\footnotetext{
2 We agree with Holt (2016, p. 8) when he says "Here I take the terms 'cybersport', 'eSport' and 'digital sport' to be synonymous, signifying physical games played out in virtual domains. That we opt for 'cybersport' in most cases is a nod to Hemphill's seminal article. Where we opt for 'eSport' instead our intention is to flag particular videogames (e.g. League of Legends) considered by many followers to count already as sports".
} 
reality that functions outside of our time constraints, expanding, slowing down, or speeding up depending on the situation; we jump to other territories, share them with people located enormous distances away, and interact in the same field of emotions. Sports stop being an issue of the "here and now" and become the place of "where" and "when", which needs no exact time, merely the players' lived experience. What does soccer contribute to children playing along that is not present when they are playing in a virtual environment? Besides the obvious differences in motor actions involved in soccer and digital sports (essential in the first case and contingent in the second), in children's eyes, both activities are real (although in one case he plays a "live game" and in the other a "virtual game") and simultaneously virtual (given that the games are a virtualization of an action). Both activities have different "levels" of virtualization and abstraction, and therefore current situations, but they do not differ from one another radically. Some play the game of football as if the ball is itself a video game console: "For some, the game is a passion; for others, it is more realistic than life itself" (De Guerre, M. and Hannah, I., 2007, p.2).

\section{The Impact of Technology on Humanity}

Sport and virtual environments have always been closely linked to technological advances. The implementation of technology into sport has resulted in the continuous improvement of sports records, for instance. Sport constantly relies on the implementation of new materials, techniques, and technologies. Sport organizations create regulations to maintain the purity of sport. In doing so, they attempt to tackle challenges arising from the implementation of technological advances that generate a profound change in sport, especially those that emphasize effectiveness and the transcendence of limitations (Echeverria, 2000, pp. 28-29).

This shows that sport technology is not neutral. It always aims to achieve something. This aligns with Heidegger's claim that technology is more than just a means to an end: "Technology is therefore no mere means. Technology is a way of revealing. If we give heed to this, then another whole realm for the essence of technology will open itself up to us. It is the realm of revealing, i.e., of truth" $(1977,12)$.

3 For Guttmann (cited on Jonasson and Thiborg, 2010, p. 292), "the development of eSport has adopted, and is still adopting, the characteristics of modern sport".
From a Heideggerian perspective, technology is a fundamental way of concealing the world. In this sense, VR could be regarded, for instance, as related to the willingness to upgrade, update, and control our situation. In Heidegger's words: "So long as we represent technology as an instrument, we remain held fast in the will to master it. We press on past the essence of technology". (1977, 17). In this sense, for Lévy (1998), Echeverria (2000), Quéau (1995) and Martínez (2008), virtual reality produces transgressive effects and consequences on reality. Although the perspective on the virtual differs between different authors, its transgressive character remains an essential element in them. Because "computer games, internet, or the most sophisticated immersive simulation systems allow us to implement and make real possibilities of communication, action, or information, that without the technologies that support them would be extremely improbable or absolutely unfeasible, if not unthinkable" (Martínez, 2008, p. 207).

Virtual simulation environments allow us to test behaviors and live entirely real situations, such as with the training of astronauts or airline pilots (Martínez, 2008, p. 207), where simulation is necessary to achieve the necessary expertise for performance of an action. This is because virtual environments "immerse users in artificial worlds and provide them with real experiences, many of which are useful for further actions in the physical and social world, whether to bomb, explore, investigate, make decisions, or have fun" (Echeverría 2000, p. 64-5). The development of $\mathrm{VR}$ and AR contributes to an increase in the control that man has over nature, simply because "that control is representative of the real character, that is to say, it restricts the presence of the present and substitutes the design and construction of representations which are undeniably, and sometimes immeasurably, effective" (Martínez, 2008, p. 207-8).

Within virtual reality, a breakthrough in the technological development of $\mathrm{VR}$ is seen in augmented reality ${ }^{4}(\mathrm{AR})$, where software allows the overlapping of technologically generated perceptions with natural ones, blurring the lines between reality and fiction (Martínez 2008, 207). AR has become

4 When we talk about virtual sport, we mean sufficiently advanced technological platforms which provides such a great similarity between the real and the virtual sport that it is difficult to differentiate between the two. We do not mean rough games in which a controller directs the action. These technologies are still developing, but we are nearing the day where virtual sport does not differ much from other activities. As Hilvoorde says: "Given the increasing application of digital technologies in traditional sports, one can argue that the worlds of virtual and non-virtual sports are approaching each other and even merging" (2016, p. 2). 
the new paradigm in the development of technology as predicted by Heidegger, where the "technological devices are shown as a kind of prosthesis that not only enable a truer vision of reality, but modify our conceptions of what may or may not be seen as such" (Martínez 2008, 207).

\section{Limits of Virtual Sport}

VR can be defined as "an artificial environment which is experienced through sensory stimuli (as sights and sounds) provided by a computer and in which one's actions partially determine what happens in the environment" (Merriam-Webster.com, 2016), which makes its analysis complex. The existence of a virtual environment depends on the perception the participant. Paradoxically, the more similar the feeling of the experience to the reality that it emulates, the less virtual it will appear to be. In the current technological state of VR, the physical and psychological risks of partaking in the actual experience ${ }^{5}$ of the sport are minimized, but as we have access to more complex VR environments, such hazards may return. This limit is found in a perfect emulation, a copy, of the very reality that it represents and imitates: the sport itself (Echeverria, 2000, p. 83).

With this, we begin to search for limits, patent in extreme sports, where the virtuoso wants to break the boundaries of that sport, and to approach the actual limits of their physical capabilities, establishing a horizon of knowledge. But the limits of a virtual game or sport, like the real activity which they represent, exist only as a horizon, as a concept. There is a world of difference between playing tennis in a virtual environment and doing it on a tennis court. It is not a question of the representation of reality, but of reality itself. They are two different realities which offer different experiences, not just a matter of the "current situation".

What leads people to play tennis on a console is different from what leads them to play on a court. The search is different. In the video game, they pursue fun, mere entertainment; in sport, they search for excellence, and the ability to transcend our limitations ${ }^{6}$. Reality represents limits, manifest in present situations rather than deferred to later,

5 AR is facilitated by implants in goggles, helmets, printed texts (QR codes) or mobile devices that allow us to gain additional elements in our quotidian worlds. It does not replace physical reality, but superimposes computer data to the real world, combining real and virtual elements.

6 As concluded by Hilvoorde \&Pot (2006, p. 12): "there are good arguments to consider eSports as 'real sports'" while virtual sport defers these limits to a later time in which they will materialize and be updated when carrying out this activity. In virtual sport, participants also seek performance, and do so in a manner to any competitive sporting environment with the federations that organize such competitions and prizes, and the spectators that make a show out of that sport. However, hermeneutic reflection about the meaning of that activity has deeper implications that transcend a mere sociological analysis of virtual sport in terms of a sporting performance. It has to do with the perception of the participant and how he considers that activity, the passage from game to sport, and therefore with the seriousness attached to such an activity. Sport, virtual or not, requires sportsmen. Therein lies the hermeneutic analysis of virtual sport: the meaning and transcendence the activity has for the participant in the activity in which he is immersed.

Such is the admiration that makes us exclaim, "It looks real!" at some of these games. With this, we mean that digital games are very close to the sport that inspires them. But why waste so much effort, technology, and imagination in making increasingly realistic virtual games that simulate real sports when we already have the original ones? This may seem like a contradiction, but it is not. The answer lies in accessibility. Virtual sports provide us with the possibility of having experiences that would have been difficult to achieve otherwise. As Henry Jenkins says, “(...) Adults need the sense of renewal brought about the game. They use another identity: try on costumes, try on masks, that is the nature of fantasy in the world of games. It allows us to feel things and be what we cannot be in everyday life" (Hannah and De Guerre, 2007).

Virtual games are about experiences; the avatar becomes an alter ego that increases the possibilities of action and interaction, breaking the spatial and temporal barriers which oppose humans in their desire to transcend nature. It is likely, in the near future when info-virtual reality technologies are fully integrated as a third environment (Echeverría, 2000, p. 79), that virtual sports will be widely practiced. We would be in command of an avatar that would interact with the -three-dimensional- physical world, not the virtual one. The avatar would be a "virtual" tool used to interact in the physical world. If this happened, it would be impossible to "distinguish between reality and unreality" (Diaz, 2011, p. 436); at that point, "we will be faced with the real irony that hides behind this constant development of the image, where the 3D is only one more stop: the reproduction of reality as faithfully and spectacularly as possible" (Diaz, 2011, p. 436). Because, in the opinion of Spiker, "computer 
games create a revolution in our way of playing and living. They may even be changing the way we think. Are they the native language of a new virtual world?" (Hannah and De Guerre, 2007).

Will VR provide us with the virtual platforms necessary for the effective passage through the barrier that delimits the possible? In a vicious -or virtuouscircle from game (ludic), we go to sport (competitive) to search for our limits, and we arrive at virtual games, effectively breaking them. It is an existential journey (because in games and sport, humans are tested), and eternal recurrence (as a dialectical process), simply offering new languages and experiential possibilities. The challenge of info-virtual reality technologies for Echeverria (2000) lies in "creating new scenarios and inventing entities that do not exist in the natural and urban environments" (p. 85). As predicted by Jonasson \& Thiborg (2010, p. 296): “The first scenario ('counterculture') can be reached relative quickly, whereas scenario two (eSport as a part of modern sport) will need more time to evolve, and scenario three ('future sport') even more time".

\section{ESports or CyberSport}

In colloquial terminology for video games, we speak of 'electronic sports', 'eSports', or 'active video games'. Some of these are online games where several players are involved, and where there is money at stake thanks to sponsorship. According to Ivo van Hilvoorde (2016, 2), “currently E-sport (or 'electronic sport') is officially accepted as sport in about 60 countries. Examples of eSports with official competitive leagues are FIFA Football, World of Warcraft, and League of Legends, which are played at the World Cyber Games". For Hemphill (2005), the proper name for eSports is "CyberSport," although he disputes the categorization of computer games as sports. Only a qualitative leap could justify the change of name from "video games" to "eSports." It is not the content that justifies whether something is a game or a sport, but the meaning ascribed to it and how it is experienced by players and/or spectators: you can play anything and with anything, and any activity in life can become a sport or a virtual sport.

Video games become sports when the culture that surrounds them becomes one in which they become

7 Ortega y Gasset (1991, p. 100) defines sport as "an effort, but an effort that, as opposed to work, is not imposed upon us. It is neither utilitarian nor paid, but a spontaneous effort. We do it for the fun of it and take pleasure in the sport itself. a show that a group of spectators enjoys watching. Some of these activities arise as mere sports-inspired games (videogames inspired on a traditional sport). Later, these games become sports (eSport), but with diminished seriousness and a strengthened ludic dimension as opposed to performance, becoming more accessible to more participants whose participation in sport would otherwise be limited, for instance, by their physical condition, among other things. To our knowledge, eSport is sport ${ }^{8}$ because: a) the subject matter is sport (or becomes sport); b) participants compete against other people rather than solely against other virtual limits; c) the expectation of the further advancement of gaming technology; and d) assume a horizon limited only by the imagination and creation of virtual worlds. Tenacity in the search for new frontiers to overcome in virtual worlds justifies the exponential growth that technology undergoes in terms of unimaginable developments and advances.

We do not take physical skills to be an essential component in the definition of sport, as Hilvoorde and Pot do $(2016,4)$. Advances in computing, telematics, and virtual worlds have expanded the limits of and possibilities of our experiences through technology. The challenge is to find a technology that allows us "to go through the mirror, and to interact with threedimensional objects, scenes, and beings that inhabit the virtual world" (Machado, 2009, p. 115, quoted in Diaz, 2011, p. 436). Electronic sports do not require a sporting subject matter. We just happen to regard them as sport. For instance, chess, which is a game of strategy, belongs to the realm of sports. Almost any activity has the potential to become an eSport. The key is to determine at what point the game becomes a sport rather than a game.

\section{Tools or Prostheses?}

Sports equipment is not a part of the biological structure of the sportsperson. Rather, pieces of equipment are tools. In contrast, the prosthetic legs of the Olympic and Paralympic athlete Oscar Pistorius are not tools, although he can run faster with them. In his sport and in his life, they are a part of him, as are glasses for someone who is myopic; they are second nature. They are not intended to increase

8 This assessment of player's ability is not incompatible with the fact that in games and virtual sports, the more capable players develop an expertise that separates the amateur from the professional. This is a result of systematic training, which can even pose a risk of ligamentous injuries in the hands or cognitive overload (Heim, 1993). 
his functional capabilities, which would make him a cyborg (Butryn, 2002), if not comparable to those without disabilities.

It is a different process from that described by Heidegger (1962, p. 115): “The kind of Being which equipment possesses-in which it manifests itself in its own right-we call 'readiness-to-hand'". Prostheses are not ready-at-hand, as the racquet for tennis is not a tool for his "uselessness", but a "being for", because they allow you to project existentially under conditions similar to those who do not need a prosthetic. Prostheses for Pistorius and a wheelchair for a paraplegic are not strictly tools, but cultural devices that allow them to be equal to other people. Extensions for the purposes of virtual sport allow participants to go beyond the equal and access new horizons . To Ivo van Hilvoorde \& Laurens Landeweerd (2010, 2226-7), "Pistorius' wish to become part of 'normal' elite sport may be framed as a way of 'inclusion' or 'integration', but paradoxically underlines the differences and reproduces the current order and hierarchy between able and disabled bodies." The prosthetic is not held. Rather, it is added and implanted. The tool, however, (a racquet or hammer) "held with the hand, is a real thing, but provides an unlimited number of possible uses" (Lévy, 1999, p. 70). For Lévy, “a tool is an extension of the body, a virtualization of action" (1999, p. 70). When something is used as a tool, in every hammering or racquet shot, it is an updating of the tool. In this regard, Lévy argues: (...) To use a tool, you must learn gestures, acquire reflexes, and remake a mental and physical identity. The blacksmith or the skier, the car driver, the harvester, the knitter, and the cyclist have all changed their musculature and their nervous systems to integrate the instruments into a kind of extended, modified, virtual body. (year?, p. 70)

Our imagination allows us to break the boundaries of the world around us; sport allows us to break these boundaries on the level of reality. In this sense, games and sports are fundamental in humans' evolutionary and adaptive process, and represent the struggle to break the boundaries of space and time (altius, citius, fortius). Languages are advancing to account for changes in imagination and technology, as are the advances that VR fosters. In this sense, the technological object, a bicycle, motorcycle, or a game of virtual cycling "serve not only a symbolic replacement function, but also perform the same type of abstraction" (Lévy, 1999, p. 78).

VR games help mankind take a step forward in the domestication of the physical environment. Sport was the first step in the symbolic apprehension of space and time; virtual sport is the last step in this attempt to overcome "the resistance of things, the immobility of nature" (Barthes, 2008, p. 75). Understanding sport as the result of a complex process of virtualization facilitated by technology brings us to an interpretation of sport an activity that, through virtualization processes, builds an intersubjective, virtual space. Electronic sport (eSport) has come true through VR, creating a new category of sports heroes that emulate extraordinary athletes. In doing so, eSports participants perform in another reality. A reality that is on a different level from our typical reality: a virtual level.

\section{Virtualization as a Humanization Process}

For Ortega y Gasset (1996), sport ${ }^{9}$ results from utilitarian activities; not the other way around. Sport precedes utility. Sports, thus, as an embodiment of the spirit of games, precede utilitarian activities. In the same vein, Suits defines game playing as "the voluntary attempt to overcome unnecessary obstacles" (1978, pp. 54-5). The creation of playful activities goes in line with the process of humanization, that is to say, with the process of substitution of natural laws with those laws that humans give to themselves. This process, arguably, is also a process of virtualization, since what is heterogeneous becomes other, but without falling into alienation (Lévy, 1999, p. 25).

For Lévy, there are three human creative virtualizations: language, technology, and contract. Through language, "humans can be partially separated from their ordinary experience, and remember, recall, imagine, play, and simulate. Thus, they take off to other places, other times, other worlds" (p. 68). Language opens us to a virtual world. In line with this, sport as a form of expression and semiotic operator throws us into the virtual reality of the game. In this sense, virtual sport operates in the "third environment" that Echeverria (2000, p. 87) defines as a "new social space generated by the communication and computing of technologies", that is, the info-virtual reality. When played at a high competitive level, sport is an activity of demigods and heroes; virtual sport, however, humanizes sport by making it accessible to all of us. Anybody can have the experiences that were reserved for a few physically gifted individuals, the

\footnotetext{
9 In relation to this, Hilvoorde reflects $(2016$, p. 2): "What should we think of Formula 1 racing in a virtual environment without the risk of real crashes, air pollution, and sound pollution? Questions like these not only deal with the potential of virtual sports, but also with our conception of current sports, and how relevant we consider elements such as health risks, real body interaction, and face-to-face contact"
} 
"chosen ones." With eSport, we are witnessing the true democratization, humanization, and universalization of the sporting experience (Sanchez and Martinez, 2014).

That virtual games are virtual does not eliminate their connection with empirical reality. Virtual games maintain a connection with praxis -with the action itself (Sanchez Vazquez 2003, 27). This connection, in a Marxist sense, is double. Virtual games have both intentional elements - the search for a particular aim - and non-intentional aspects - the search for global results of interaction with other praxis (Sanchez Vazquez 2003, 16), exceeding the utilitarian aspects of the practice. With practice and training, virtual games and eSports played on consoles like PlayStation, Wii, and Xbox increase our coordination, motor capabilities, and spatio-temporal capacities. However, virtual games and eSports do not produce anything beyond themselves. In this sense, it is understood that the virtual character of those games is at odds with the Greek poesis, that is, with the production or manufacture of something. Instead, the game is praxis in its "conscious objective activity" (Sanchez Vazquez, p. 28).

"Moreover, the virtual game or sport should look like the actual sport or activity (one in which it is inspired), imitating sensations, sets, props ... but safeguarding the physical and moral integrity of the player; otherwise, it would be a new sport. Faced with this problem, the fundamental question is whether the evolution of virtual sports is generating other sports, different from those that inspired them, or whether it provides simply to enjoy a similar experience to "regular" sport, and emulates, democratizes, and humanizes sport, making it accessible to a greater number of people and less "capable"10. Time will answer this question."

\section{The Playful Utopia}

"Virtual" is etymologically associated with "virtue" and assumes implicitly some value. VR is a newly existing "space" without a precise location (Echeverría, 2000, p. 15), next to utopia, which serves to guide us, to make us human (Sanchez and Martínez, 2014), and to make life bearable. Because "utopia and science are the basic faculties of man in sync with his very being that

10 Of human limits, which can be transcended through VR, we must not forget that virtual games also possess certain limitations, those that Poole (quoted in Hemphill, 2005, pp. 200) calls "incoherence of causality, functionality, and space". However, the evolution of technology will potentially overcome them, but these still remain an impediment to consider in current virtual or cyber sports. behaves both intelligibly and unintelligibly" (Flores, 2008), both come together in VR, putting the playful utopia within our reach, perhaps as a substitute for

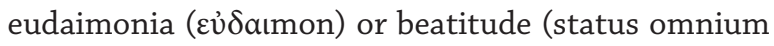
bonorum congregatione perfectus). The virtual space where virtual games take place is utopia, but made concrete, and operating through playfulness. Virtual games offer us myriad emotions and sensations accessible through a "hyper-body" that transcends the realm of traditional sports, making these experiences more human and democratic. Indeed, virtual reality is also utopia because it is a place that does not exist in reality but virtually.

Some myths have inspired the practice of activities that eventually became virtual: the anthropological myth of flying (Icarus) was possible when technology gave us the wings from our imaginations, allowing us to take of the ground and physically soar through the air. It is the passage of myth into reality that allows for the "becoming-sport" of aerial sports (from the hang glider to aerobic aviation), where playfulness makes us forget the real. With flight simulators, you learn to fly a plane. If you only want to recreate the sensation of flight, this reinforces the playful component; if you gain a dimension of performance and selfimprovement, it can be transformed into a profession or sport.

But, what is lost and what is gained in the transition from the mythic to the virtual? This route has a holding point around the real: from myth to reality, and from reality to the virtual. The myth is also true to those who live it, as is the virtual world, simply using different languages to express the same feeling. When we think of flying, we recreate it; when we really fly, we are barely able to imagine it, because the current action prevents us from being entirely aware of it.

Sport takes us into a sphere of suspended reality where there are signs of what to do immediately as we are doing it. This a state that Hyland (1990, p. 79-80) defined as "peak experience," where the athlete is "in the zone" and acts without thinking. Then the unconscious athlete comes out, described by sports commentators as being "on fire," as Hyland describes. These experiences resemble other tasks of life in which our skill level allows us to act without thinking, or simply elevate ourselves to another level of thought: that of excellence, a body and mind fusion (Sanchez, 2014) which leads to the dissolution of old and atavistic dualisms: "Body and mind are one reality and cannot be understood in isolation" (Sanchez, 2006, p. 119). That is why sport is an intermediate step between myth and reality, and between reality and virtuality. 


\section{Understanding Virtual Sport}

Understanding certain activities like virtual sports is not far from understanding communication (a traditional face-to-face conversation) through cell phones or video conferences via Skype; virtual sport is a technological advance applied to natural human activities. However, we must not lose sight of the fact that we are dealing with substitutes, or conventional human actions that are facilitated by technology. There are also certain risks with the loss of face-to-face relationships because of the proliferation of chats and other anonymous messaging services. For example, when considering "the impact of gaming on the lives and leisure time of children, one is still overwhelmed by topics like game addiction, violence, aggression, gaming disorder, desensitization to violence, obesity, and all kinds of pathologies that might correlate with playing video games" (Spitzer 2012, cited by Hilvoorde, 2016, p.1). Heidegger (1977, 5) pointed out that modern technology is turned against human beings, "away from its natural essence to place it on the artificial construct that determines our world and our environment" (Terino 2010, 15-16).

The difference between virtual games and virtual sport lies in the consequences of the actions that take place in them. The virtual game is recreation where the ludic element prevails, while in virtual sport, the result has an influence on the whole experience. In virtual games, we are participating in a "laboratory test," which provides great propaedeutic value to try and test other experiences and skills: "virtual reality is a new kind of scientific method which can be used to watch, test, experiment, and teach" (Echeverria, 2000, p. 50). As argued by Hilvoorde \& Pot (2016, p. 1 ), "eSports do require the learning and performance of motor skills and that embodiment within a virtual environment may be considered playful or even athletic."

In virtual sports, there is no possibility of correcting virtual sport with virtual games, because the seriousness of the competition and the struggle for victory exclude mere entertainment. That is to say, in virtual sport, there is no possibility of rectifying competition, the serious search for the results, with the game, or the ludic, playful element. In fact, even in computer games it is necessary to "train" 11 and practice to compete and win, that is, "to become sport". What enables this transition from games to competition is seriousness. The game is a game, and it is not sport because it is not serious. Sport is, among other things, the relevance, significance, importance of results, and it is what is at stake in sport that gives it a distinct nature from games, whether virtual or not. In fact, the biggest drawback of regarding sport as eSport lies in the excessive dualism that separates the physical from the mental, the intellectual and the affective (Sanchez, 2012, Sanchez and Gutierrez, 2012). The transformation of the physical experience into a different experience through a virtual platform does not eliminate the sporting dimension of the activity, as it is likely to retain the emotional, social, and intellectual experience of sport, and potentially even increase them, generating new forms of reality (Echeverria, 2000, 121).

\section{Conclusion}

Sport hermeneutics must follow the path marked by Quéau (1995) and think about the challenges that the exponential growth of technology raises: focusing on technological developments themselves rather than on classical philosophy or contemporary thinkers. Therefore, instead of speculating on a priori philosophical principles of virtue, "the next step is to analyze the actual changes brought about by new computing technologies" (Echeverria, 2000, p. 141), and to establish a conceptual reference point as a hypothesis to fit in all of these inexorable technological changes. Such a point of reference may be the third environment (Echeverria), the virtualization (Lévy), or for virtual sport, the process of humanization (Sanchez) generated by sport since the dawn of mankind, apprehending nature in our pursuit of excellence and seeking to transcend the limits that it imposes on us. Sport is a human activity independent of the environment in which it is performed, whether real, virtual, or present. Eventually, virtual reality and virtual sports will be normalized, bringing us back to confronting limitations and real consequences. A motorcycle allowed us to move without the effort of pedaling, but its sportization (motorcycling) requires effort and training. Human beings develop technology to facilitate everything, but we eventually return to sports, and thus effort (physical and mental) returns with it. This is what prevents us from losing our humanity.

11 According to Kang Min, StarCraft player, "if you start as a teenager, you can get in as much as ten years. As in any sport, you become weaker with age" (Hannah and De Guerre, 2007). 
Barthes, R. (2008). Del deporte y los hombres [Sport and men]. Barcelona: Paidós Ibérica, S.A.

Butryn, T. (2002). 'Cyborg Horizons: Sport and the Ethics of Self-Technologization.' In A. Miah, \& S. Eassom (Eds.), Sport Technology: History, Philosophy and Policy. Research in Philosophy and Technology. Vol. 21 Series Ed: Carl Mitcham. Oxford: Elsevier Science Ltd.

Díaz, V. (2011). Espectadores de 3D: ¿El futuro del cine? [3D Spectators: The future of cinema?]. ARBOR Ciencia, Pensamiento y Cultura, 748 (187), pp. 429-438.

Echeverría, J. (2000). Prólogo. Vértigo real de lo virtual. En Un mundo virtual [Prologue. Real vertigo of the virtual. In A Virtual World] (pp. 13-19). Barcelona: Debolsillo.

Ferrater, J. (1956). Diccionario de Filosofía [Dictionary of Philosophy], To. 1, $4^{a}$ edición. Buenos Aires: Editorial Sudamericana.

Flores, G. (2008). Homo utopicus. Una reflexión onto-antropológica sobre la utopía [Homo utopicus. An on-anthropological reflection on utopia]. Available at http://www.librosperuanos.com/articulos/gustavo-flores12.html

Hannah, I. y De Guerre, M. (2007). Documental: Sangre, sudor y videojuegos: poder sobre la mente [Documentary: Blood, sweat and video games: power over the mind]. Cap. II. Canadá

Heidegger, M., Robinson, E., Dr, \& Macquarrie, J. (1962). Being and time. New York: Harper.

Heidegger, M. 1991. Ser y Tiempo [Being and Time]. Madrid: Fondo de Cultura Económica.

Heidegger, M. (1977). The Question Concerning Technology and Other Essays. New York \& London: garland publishing, Inc. 3-35.

Heidegger, M. (2000). Nietzsche II. Barcelona: Destino.

Heim, M. (1993). The Metaphysics of Virtual Reality. New York: Oxford University Press.

Hemphill, D. (2005). Cybersport. Journal of philosophy of sport, 32 (2), pp. 195-207.

Hilvoorde, I. v. \& Pot, N. (2016). Embodiment and fundamental motor skills in eSports, Sport, Ethics and Philosophy, 10 (1), pp. 88-96, DOI: 10.1080/17511321.2016.1159246.

Holowchak, M.A. (2007). Games as Pastimes in Suits's Utopia: Meaningful Living and the "Metaphysics of Leisure", Journal of the Philosophy of Sport, 34(1), pp. 88-96, DOI: 10.1080/00948705.2007.9714712

Holt, J. (2016). Virtual domains for sports and games, Sport, Ethics and Philosophy, 10 (1), pp. 1-9. DOI: 10.1080/17511321.2016.1163729

Hyland, D. (1990). Philosophy of Sport. New York: Paragon House.

Jonasson, K. \& Thiborg, J. (2010). Electronic sport and its impact on future sport, Sport in Society: Cultures, Commerce, Media, Politics, 13(2), pp. 287-299.

Lévy, P. (1999). ¿Qué es lo virtual? [What is virtual?]. Barcelona: Paidos.

Mandell, R. D. (1986). Historia Cultural del Deporte [Cultural History of Sport]. Barcelona: Bellaterra.

Martínez, P. (2008). Técnica y realidad: hacia una comprensión de lo virtual [Technique and reality: toward an understanding of the virtual], Ontology Studies, 6, pp. 199-208.

Morgan, W.J. (1991). The Philosophy of Sport: An Overview, by Robert G. Osterhoudt (Champaign, IL: Stipes), Journal of the Philosophy of Sport, 18, pp. 86-89.
Ortega y Gasset. J. (1996). Obras Completas [Complete works], vol. II, pp. 607-624. Madrid: Revista de Occidente.

Osterhoudt, R. G. (1976). In Praise of Harmony: The Kantian Imperative and Hegelian Sittlichkeit As the Principle and Substance of Moral Conduct in Sport, Journal of the Philosophy of Sport, 3(1), pp. 65-81, DOI: 10.1080/00948705.1976.10654115

Osterhoudt, R. G. 1991. The Philosophy of Sport: An Overview. Champaign, Illinois: Stipes.

Prensky, M. (2001). Digital Natives, Digital Immigrants, On the Horizon, 9, pp. 1-6, octubre. [http://www.marcprensky.com/writing/Prensky \%20-\%20Digital\%20Natives,\%20Digital\%20Immigrants\%20-\%20 Part1.pdf] <23-5-08>

Quéau, P. (1995). Lo virtual. Virtudes y vértigos [The virtual. Virtues and vertigos]. España: Paidós

Sánchez Vázquez, A. (2003). Filosofía de la praxis [Philosophy of praxis]. México: Siglo XXI editores.

Sánchez, A. (2006). Filosofía y Deporte [Philosophy and Sport]. In A. Pereira, A. Costa, R. \& García (Eds.), O desporto entre lugares. O lugar das ciências humanas para a compreensão do desporto [The sport between places. The place of the humanities for the understanding of sport], pp. 101-124. Porto: Faculdade de Desporto.

Sánchez, A. (2012). El filósofio del deporte [The Philosopher of Sport]. Ágora para la EF y el Deporte, 14 (3), pp. 359-369.

Sánchez, A. (2014). Filosofía y gimnasia: Tareas del filósofo del deporte [Philosophy and Gymnastics: Tasks of the Philosopher of Sport], Revista de Occidente, 392, pp. 45-62.

Sánchez, A. y Gutiérrez, J.Ma . (2012). Mind and body versus Gymnastics and philosophy: from dualism to emergentism. Cultura, Ciencia, Deporte, 19 (7), pp. 5-18.

Sánchez, A., Martínez Castro, S.M. (2014). Deporte y realidad virtual: la utopía lúdica humanizadora [Sport and virtual reality: the humanizing playful utopia]. En M.P. Sancho y S. Viñao (Coord.), Impulso Humano (pp. 16-58). Murcia: Universidad Católica San Antonio.

Spitzer, M. (2012). Digital dementia: What we and our children are doing to our minds. Munich: Droemer Verlag.

Suits, B. (1977). Words On Play, Journal of the Philosophy of Sport, 4(1), pp. 117-131, DOI: 10.1080/00948705.1977.10654132

Suits, B. (1978). The Grasshopper: Games, Life and Utopia. Broadview Press.

Suits, B. (1988). Tricky Triad: Games, Play, and Sport, Journal of the Ph hy of Sport, 15(1), pp. 1-9, DOI: 10.1080/00948705.1988.9714457.

Terino, T. (2010). Heidegger y la pregunta por la técnica [Heidegger and the question by technique]. Editorial Edita.

Van Hilvoorde I \& Landeweerd L. (2010). Enhancing disabilities: transhumanism under the veil of inclusion? Disability and Rehabilitation, 32(26), pp. 2222-2227.

Van Hilvoorde, I. (2016). Sport and play in a digital world, Sport, Ethics and Philosophy, 1-4, DOI: 10.1080/17511321.2016.1171252

VV.AA. (2001). Diccionario de la Lengua Española [Spanish dictionary]. Real Academia Española.

Virtual reality. (n.d.). Retrieved September 10, 2016, from http://www. merriam-webster.com/dictionary/virtual reality 